\title{
Introduction
}

Why do so many parents vaccinate their children? On a superficial level, this seems like an odd question. In recent years, public health professionals around the world have been much more concerned with parents who do not. A high-profile outbreak of measles in 2015 in Disneyland, California created headlines around the globe, leading the state government to reassess its policy for granting vaccination exemptions. ${ }^{1}$ Meanwhile, rising morbidity in Western Europe in 2017 caused many nation-states to increase efforts to vaccinate children against measles, with some even resorting to compulsion. ${ }^{2}$ Both in academic and popular media, anti-vaccinationism has been blamed for these trends. In the global North, communities of activists, buoyed by the internet and social media, have caused headaches even in long-established public health systems. ${ }^{3}$ Attacks on health workers in the twenty-first-century Global Polio Eradication Initiative showed that resistance to vaccines was still very much a live issue in low-income countries, too. ${ }^{4}$ Even where the scientific case has been successfully made that vaccines reduce the burden of infectious disease, moral and ethical concerns can cause much debate. For instance, in the 2010s the human papillomavirus (HPV) vaccine has highlighted trials on human subjects in lowincome countries, the potential sexualisation of teenage girls and whether it is acceptable to gender public health responses by excluding boys from routine vaccination programmes. ${ }^{5}$

Despite these anxieties, most citizens and media commentators have appeared to be convinced of the power of vaccination. In February 2016, when the Zika virus was found to cause microcephaly in children born to infected mothers, governments and research institutions around the world clamoured for a vaccine to stem the outbreak. ${ }^{6}$ The same was 
true six months earlier, when the Ebola crisis was declared a Public Health Emergency of International Concern. ${ }^{7}$ As for Britain, in 2014-15, 92.3 per cent of children under the age of two years in England received their first dose of measles-mumps-rubella vaccine (MMR) and 94.2 per cent completed their course of vaccines against diphtheria, tetanus, pertussis (whooping cough), polio and Hib (the five-in-one vaccine). ${ }^{8}$ Rates in Scotland were even higher. ${ }^{9}$ In a 2016 survey conducted by the Vaccine Confidence Project at the London School of Hygiene and Tropical Medicine, 89.6 per cent of British respondents agreed or strongly agreed that vaccines were important; 84 per cent agreed that they were safe; and 86.7 per cent agreed that vaccination was effective. ${ }^{10}$ These vaccines have been actively accepted, not just passively tolerated. British parents actively demanded protection for their children. When Faye Burdett, a two-year-old girl from Kent, died of meningitis in February 2016, her parents began a campaign to raise awareness of the existence of the meningitis B vaccine. Ex-England Rugby Union captain Matthew Dawson, whose own son nearly succumbed to the disease, gave added publicity to the cause and it caught national media attention. Over 800,000 people signed a petition demanding that the vaccine be given free to all children, not just those who had been born after 1 July 2015. It was the most-signed online petition since the UK government set up the UK Government and Parliament petitioning system. ${ }^{11}$ It appeared that Britain, like the United States, had accepted what Jacob Heller calls "The Vaccine Narrative" - 'We simultaneously understand vaccines as a shield against diseases, a rite of passage for children and parents, and an expression of our science, civilization and morality. ${ }^{12}$

This book examines how the routine immunisation of children became the status quo in Britain after the Second World War. It tells the story of how vaccination programmes became established in the modern British welfare state, how they expanded and how they were maintained. Successive British governments achieved this by responding to various challenges, including vaccine shortages, public scepticism over safety, scientific controversies and supply logistics. The schedule expanded from just two disease-prevention programmes in 1945 (smallpox and diphtheria) to around twenty routine and optional vaccines in $2018 .{ }^{13}$ But this was not simply a government project to improve public health. The British public played a key role in shaping the priorities of the programme, in turn placing expectations on the British state 
and their fellow citizens. To turn the subtitle of Stuart Blume's latest volume on its head: this is not about "how vaccines became controversial"; it is about how they became ordinary. ${ }^{14}$

It would be obtuse to suggest that vaccines and vaccination are - or have ever been - uncontroversial. There have been countless disputes over the role of the pharmaceutical industry, state power, individual liberty, the diseases from which people require protection, the extent to which science should interfere in "natural" disease patterns and many more besides. ${ }^{15}$ We have seen periods in which immunisation rates dropped dramatically as a result of losses in public confidence, most notably the 1970s (whooping cough) and 2000s (MMR). But such drops suggest a relatively robust "normal" from which they could fall. Parents in post-war Britain were much more likely to vaccinate their children than not, and compliance with recommended schedules increased significantly over that time. This volume does not attempt to analyse the individual or social psychologies surrounding decision making about vaccines (topics better addressed by other social science disciplines). Instead, it uses periods of disagreement between various government and public bodies over the post-war period to show how the relationship between the British state and its citizens forged the modern vaccination programme. In the 1940 s it was not inevitable that public health and the British public would embrace vaccination in the form that they did. Rather, this emerged from a series of developments in vaccine technology, the expansion of the welfare state and changing expectations on the part of both the government and the public. Moreover, through investigating how vaccination policy changed in post-war Britain we begin to understand the fluid and changing role of the public in the practice of public health.

\section{Vaccination in history}

When the story of post-war vaccination is told by public health advocates, it is usually one of progress. ${ }^{16}$ This is said to occur on both a scientific basis (the discovery of new techniques leading to the development of new vaccines) and a political one (the development of various administrative and bureaucratic systems for the effective delivery of vaccines to the masses). ${ }^{17}$ While vaccines have not been the only factor in reducing morbidity and mortality from once-common diseases, 
epidemiologists are almost unanimous that improvements in the manufacture, administration and education surrounding vaccination have been vital. ${ }^{18}$ Such narratives stress how dangerous infectious diseases were in the past and how their risks have been significantly reduced through the work of public health. ${ }^{19}$

While these Whiggish histories serve a useful political purpose, enhancing the reputation of disciplines and governance structures allied to public health, they do not critically reflect on how the growth in vaccination came about. Where there have been investigations into problematic areas of vaccination, they have focused on crises in confidence, but do so in a way that assumes that the default and rational position of the public is to support vaccination. Declines in vaccination rates or resurgences in once-controlled diseases are thus framed as aberrations caused by outside, irrational factors. Thus, the pertussis vaccine scandal of the 1970s or the MMR controversy of the 1990s and 2000s are studied from the perspective of "what went wrong", in order to prevent or manage such crises in the future. ${ }^{20}$ Historians of medicine are wary about "learning lessons". ${ }^{21}$ Rather, we tend to investigate the past to understand how people understood health, illness and medical care. These concepts are held to be historically contingent, and meant different things to different peoples at different times. How the public responded to new medical technologies or impositions from governments and health authorities can tell us much about cultures of the past. Existing studies of vaccination, for instance, have exposed Victorian attitudes towards the limits of local and national government, ${ }^{22}$ while comparative analyses of poliomyelitis vaccines have shed light on the cold-war geopolitics surrounding the trustworthiness of capitalist or communist epidemiological practice and medical ethics. ${ }^{23}$ Crucially for this study, work on diphtheria and tuberculosis immunisations has highlighted how different nation-states' cultural attitudes towards medicine and science produced very different interpretations of the same scientific data. ${ }^{24}$ This, in turn, resulted in very different policy choices and outcomes.

Given this history, it is clear that vaccination programmes - like any other political project - are rooted in a wider social context. This book explores this through a series of case studies which highlight the ways in which the public and governments interacted, shaping public health as they went. What was expected of the public and of the government 
changed over this period; and the debates over vaccination show wider concerns about the relationship between the state, its citizens and the nature of public health governmentality. ${ }^{25}$ The book does this by building on existing histories of specific diseases and vaccine crises. This has been a common feature of the historiography of British immunisation policy. Works on the introduction of BCG (Bacillus Calmette-Guérin, an anti-tuberculosis vaccine), diphtheria immunisation, polio vaccine and hepatitis B vaccine have given insight into the scientific, political and cultural context of vaccination and how it was received by the public. ${ }^{26}$ Less attention has been paid to the mundane business of established immunisation programmes which did not cause significant controversy. It is generally assumed that health care priorities shifted away from infectious disease control to hospital medicine in the National Health Service (NHS) era, giving an impression that there is nothing of note to study. Where public health is covered, more attention is paid to the management of lifestyles and risk factors. ${ }^{27}$ Indeed, Rudolf Klein does not even mention public health in his comprehensive history of the NHS until the HIV/AIDS crisis of the 1980s. ${ }^{28}$

This volume also finds meaning in periods of contestation and in the public attention generated by new vaccines; but by analysing the vaccination programme across the post-war period, we also gain a sense of what made vaccination normal for so many parents. Indeed, the uneventful, mundane administration of vaccination programmes was not peripheral to the history of public health as one might suppose from the literature: it was central to it. The very fact that it has not excited much attention is a testament to how well the concept was established. This book traces how this was done through the early post-war period, and expanded and entrenched during the 1970s and beyond.

This is not to say, however, that notable works on immunisation in general do not exist. James Colgrove's excellent study of vaccination in the twentieth-century United States acts as an instructive contrast to the British story; for instance, there was little fear in the United Kingdom that polio was the harbinger of "socialized medicine", nor did British subjects have problems accessing many vaccines on account of fees charged by private family physicians. ${ }^{29}$ Similarly, Bob Reinhardt and Sanjoy Bhattacharya have expertly analysed the smallpox eradication programmes in Africa and Asia with a critical gaze on dominant constructions of global public health and the scientific and administrative 
procedures which underpinned their success in eliminating the disease in the wild. ${ }^{30}$ Most recently, Stuart Blume has detailed the scientific development of vaccination technology and the reasons why vaccination has been controversial across the world. ${ }^{31}$ These are still rare exceptions, and until now there has not been such a comprehensive review of the public and vaccination in post-war Britain.

There are also works that have explored the relationship between the public and public health in the United Kingdom. There is a wellestablished scholarship on such matters in the nineteenth century and on the changing nature of public health governance in the first half of the twentieth century. ${ }^{32}$ For the period after 1945, there is growing interest in the meaning of the concept of "the public" within public health, on the part of practitioners themselves and of historians. But while vaccination has been used in part to illuminate this relationship - notably in the work of Roberta Bivins on ethnicity and public health with regard to tuberculosis and smallpox in immigrant populations none has centred their analysis on the wider context of mass vaccination in post-war Britain. ${ }^{33}$

This is important because Britain's vaccination programmes give new insights into how the relationship between the government and its citizens changed after 1945. It was precisely because infectious disease had become preventable that the public placed greater expectations on the government and fellow citizens. ${ }^{34}$ Outbreaks became less common, but were a bigger scandal when they occurred. Governments that were unable to plan and run large-scale immunisation programmes were seen as deficient. This book helps to explain how and why vaccination was a key tool in protecting not just the health of the British people but the reputation of public health and the British state in general. These issues of citizenship were not simply a product of an age of consumerism or individualism that is assumed to have developed during the 1970s and under the New Right governments of the 1980s. ${ }^{35}$ During immunisation campaigns in the 1940s questions were raised about the role and responsibility of citizens for their own and their families' health. Similarly, the technologies of managing risk, often attributed to the 1970 s and beyond, were present in an earlier period. ${ }^{36}$ Many of the facets of a supposed golden age of technocracy existed both before and after the heyday period of the late 1950 s to mid-1970s. ${ }^{37}$ As these 
chapters show, targets, statistical monitoring and central direction of regional authorities were employed throughout the post-war period in attempts to immunise the population and reduce the burden of preventable disease.

As with any work of historical scholarship, the researcher must make choices not just about what is included, but also about what must, for reasons of space, time and coherence, be excluded. This book will at no point attempt to assess whether or to what extent vaccines "really" worked, or their relative safety. History does not use the same tools as epidemiology, and these are scientific questions that must be answered using the methods laid out by other disciplines. In any case, these subjects have been tackled in depth both by contemporaries and by those reading back over the extant data. ${ }^{38}$ Similarly, deep qualitative analysis of the public's understanding and construction of narratives surrounding vaccination across time are not possible in a volume such as this. Aside from methodological and philosophical issues in determining who the "ordinary" person is, governments have produced far more documentary evidence, and have preserved it in such a way that it is much more accessible to historians. ${ }^{39}$ Folklorists are better positioned to explore this terrain, but even here there will be significant issues in accessing the memories of those who are no longer alive to tell their stories. ${ }^{40}$ This is not to say that the public is not present in this volume. Members of the public continued to speak back to authorities and each other through letters, public utterances and more diffuse behaviours for which we can find empirical evidence. ${ }^{41}$ Instead, this analysis addresses how concepts such as safety and efficacy were expressed by health authorities, politicians, the medical profession, the media, nongovernmental organisations and, indeed, members of the public themselves. It is through these that the wider relationship between the public and public health can be grasped.

Not every vaccine used in Britain since the Second World War can be covered in detail. This book focuses on routine childhood immunisation - which necessarily excludes vaccines given to foreign travellers (such as yellow fever), to protect individuals at immediate risk (rabies), to protect subgroups of people considered to be at potential risk (hepatitis B, before 2017) or to protect the military from bioterrorism (anthrax). Even widely used vaccines, such as those against influenza, 
HPV or tuberculosis, are not given their own chapters. There were also vaccines for which the public and medical authorities expressed a desire (such as for HIV/AIDS) but which were never developed. ${ }^{42}$ Where these diseases and their associated immunisation are relevant to the overall narrative, they will be discussed. However, the chapters that are included here exemplify the broad trends and concepts that are crucial to understanding the relationship between the public and public health authorities during the post-war period.

Finally, any history of Britain needs to engage with the "four nations" question. Political events from devolution in the 1990s to the Scottish and European independence referenda in the 2010s have made British citizens even more aware that "Britain" is not simply "England". The Ministry of Health and its successors had direct jurisdiction over England and Wales, and evidence from these regions is given greater focus than that from elsewhere in the Union. However, it is important to stress that vaccination policy in Britain was British. Until 1974, local authorities had responsibility for the implementation of vaccination programmes through Section 26 of both the National Health Service Act 1946 and National Health Service (Scotland) Act 1947. But many of the decisions over immunisation policy at national level were taken cooperatively. As will be shown in Chapters 2 and 3, the "Joint" in Joint Committee on Vaccination and Immunisation refers to the cooperation between the Scottish, Northern Irish and English health authorities on vaccination. Local and national bodies worked with and learned from each other within this framework. Where appropriate, Scottish examples are used to highlight these national issues (such as the 1949 Glasgow smallpox outbreak, or differences in approach between English and Scottish health authorities during the MMR crisis). The focus here is not on particular British cultures of vaccination, but on the British vaccination system. The administrative links between and across regional, national and transnational public health bodies were all important in creating that system.

\section{Vaccination and the public}

As indicated in much of the existing literature, the development of vaccination programmes in Europe during the eighteenth and nineteenth centuries was intimately connected with the expansion of central state 
authority over the public's health, and a widespread political contestation of the precise limits of state authority in relation to the citizensubject. Vaccination has been associated with state power ever since. Indeed, this contested relationship between individual liberty and collective responsibility with regard to infectious disease control has been central to debates over vaccination and other public health programmes. ${ }^{43}$ Who "the public" are within these structures is difficult to define precisely. Where we can discern attempts to define publics (both by contemporaries and by later analysts), we see them mainly through two lenses. There is what we might call a demographic approach, which views publics as populations of people that can be measured according to some set of common criteria. Then there is an identity approach, in which the public as a mass collection of individuals believes itself to have common attributes that allow it to exist as a political force. Thus, publics could be constructed through governance structures as well as construct themselves through voluntary or mutual action. ${ }^{44}$ Publics could and did speak and act in myriad ways that disrupted public health policy, and their concerns changed over time. However, this book does not provide a grand unifying vision of who or what the public really was in post-war Britain. Instead, it investigates the ways in which authorities constructed ideas of the public through their vaccination policies. Here, governments identified problems, measured their effects and interpreted the public's behaviour on their terms. But, in doing so, the public spoke back, often complicating authorities' plans and forcing new interpretations of policy. For the government, the voices of individuals and of the public in general were always mediated through these interactions - and the complex ways in which these shone through tell us much about post-war British politics.

Whatever our conception of "the public", public health has maintained a disciplinary function, and much has been written about how governance structures acted upon the public from a medical perspective. ${ }^{45}$ Somewhat paradoxically, the imprecision of definitions of "the public" and "public health" have, according to Jane Lewis, been both a strength and a weakness of public health governance and the public health profession. ${ }^{46}$ In the supposed heroic age of the nineteenth century, large-scale infrastructure projects, such as water purification and sewerage, had a demonstrable impact upon the health of urban environments following the rapid urbanisation that began in the 
previous century. Such projects were pushed through by national governments despite objections from local authorities; although it should be noted that local innovation and pressure often had an impact on national policy and the understanding of public health problems. ${ }^{47}$ As health systems developed and the power of medical science increased, Medical Officers and local authorities became more heavily involved with the running of municipal hospitals and other Poor Law institutions such as asylums. The looseness of the definition of public health thus allowed Medical Officers to gain significant power during the nineteenth and early twentieth centuries. Yet, as Lewis argues, it also meant that once health systems became increasingly complicated and relied upon ever-centralised power (such as the creation of the NHS), public health became a side-lined profession. ${ }^{48}$

John Welshman and Martin Gorsky have questioned this narrative, arguing that Medical Officers of Health (MOHs) continued to perform important public health functions. ${ }^{49}$ It is generally acknowledged, however, that public health transitioned from concerns about infectious disease and epidemic control towards the management of chronic conditions. As hygiene improved, issues such as lung cancer and heart disease proved more pressing. Virginia Berridge tracks this evolution in post-war public health through the lens of smoking. ${ }^{50}$ The story of postwar vaccination complicates this picture. MOHs and the British government in general put significant resources into vaccination in the name of controlling infectious disease. This was not in the same vein as the large Victorian sanitation projects, nor were $\mathrm{MOHs}$ called into action to contain outbreaks of diseases such as smallpox with the same regularity as in previous decades. But infectious disease did not disappear. Rather, the risk of infectious disease became the subject of public health intervention. And, as Berridge also notes of smoking, this did concentrate more closely on individual behaviour, use of the mass media and evidence-based medicine. ${ }^{51}$

Practices of immunisation are woven into this wider history of public health, with the resistance against, and slow uptake of, these technologies haunting government perceptions of the public and vaccination long into the twentieth century. Variolation - the introduction of smallpox into a healthy person to give them a mild form of the disease and confer immunity - was popularised among the British nobility in the early seventeenth century by Lady Mary Montagu. ${ }^{52}$ The development 
and growing acceptability of inoculation techniques, and statistical methods for assessing their efficacy, led some local authorities to use the technique on a wider population as a form of public health protection. ${ }^{53}$ Edward Jenner's experiments with cowpox provided a new, safer form of immunisation against smallpox in time for the aforementioned growth in the centralised state public health apparatus. ${ }^{54}$ Various Vaccination Acts over the Victorian period placed a duty on local authorities to provide vaccination free of charge, and in 1853 made routine childhood vaccination compulsory. ${ }^{55}$ This caused much resentment from a number of constituencies, creating large anti-vaccination societies that objected to the procedure on the grounds of local autonomy, scientific doubt, personal freedom, the intrusion of the state into private matters of child rearing, religious objection, animal rights and resentment at the use of Poor Law institutions to treat the middle classes. ${ }^{56}$

Developments in bacteriology and medical procedures that had given rise to the power of biomedicine and hospital-based medicine in the late nineteenth century also provided new avenues for vaccination. ${ }^{57}$ Louis Pasteur's work with anthrax, rabies and fowl cholera showed that attenuated forms of the microbes could perform a similar function to vaccination - and, more crucially, that it was possible to mass produce them. ${ }^{58}$ However, these were products of a pre-immunology age; it would not be until the very end of the nineteenth century that such developments in bacteriology were met with reformulations of scientific conceptions of immunity and disease transmission. ${ }^{59}$

The production of diphtheria anti-toxoid and its use in mass immunisation campaigns was, as Esteban Rodríguez-Ocaña has described it, 'the crucial link between public excitement about Pasteur's rabies vaccine and the establishment of national campaigns against tuberculosis, sustaining the development of bacteriology-based public health service. ${ }^{60}$ The growing power of biomedical sciences was thus embodied in these new technologies that borrowed from generally accepted principles of immunity. ${ }^{61}$ Through example, mass vaccination programmes showed that science possessed the tools not only to discover new prophylactics, but to use them effectively to prevent disease. The articulation of the concept of "herd immunity" in the 1920s gave further statistical credence to the emerging science of immunology. ${ }^{62}$ It also showed science's power to react to contemporary problems. Pasteur's anthrax vaccine, for example, was a direct response to the effects of the 
disease in cattle on agricultural output. ${ }^{63}$ Diphtheria had been identified as a distinct and significant epidemic disease only in the wake of mass urbanisation in Europe during the mid-nineteenth century. By the end of the century, an anti-toxoid had been developed. ${ }^{64}$

These advances were embraced by local and national governments as symbols of their own advancement and ability to solve complex problems. Governments employed developments in mass communication to ensure that people took advantage of the new vaccines. In New York City, newspapers, poster advertising, the cinema and the wireless were all employed to proclaim the benefits of diphtheria immunisation. Vaccination was offered as a choice, advertised as one might market an automobile; not imposed by the state as had been common for smallpox. ${ }^{65}$ When Britain initiated its diphtheria programme in 1940, it followed New York's lead by focusing on education rather than compulsion. Such tactics had worked in other fields (such as domestic cleanliness), and helped to establish the narrative that liberal British public health worked with its public, rather than imposing an authoritarian state medical police as had been seen in imperial Germany. ${ }^{66}$ British public health authorities openly sought the cooperation of their subjects, rather than compliance alone - though it is instructive that the Ministry of Health continued to refer to its advertising efforts as "propaganda" well after the end of the War. The role of education in constructing and communicating with the public is a key theme of twentieth- and twentyfirst-century public health, and will be a recurring theme throughout this book. ${ }^{67}$

While diphtheria immunisation and BCG were embraced by some nations and integrated into their public health programmes in the inter-war years, Britain was more cautious about using these new technologies. ${ }^{68}$ Linda Bryder's and Jane Lewis's work has shown that epidemiological evidence on vaccination could be interpreted in different ways by nation states. ${ }^{69}$ Thus, while one country could justify the use of a particular vaccine, another could see the same immunisation as unsafe or ineffective as compared to existing practices. The British medical establishment considered its anti-tuberculosis measures - including inspection, notification, sanatoria, dispensaries, hospital care and pasteurisation - to be adequate. Rates of infection from tuberculosis and diphtheria also appeared to be lower in Britain than they were in countries that used immunisation, such as France and the Nordic states. ${ }^{70}$ 
Such a significant change in public health policy was a risk which the British authorities were not willing to take in the 1930s for fear of damaging their reputations. Local governments were given the power to initiate their own campaigns if they so wished but, given that they needed to pay for the vaccines themselves, coverage was inconsistent and often depended on the priorities of the $\mathrm{MOH} .{ }^{71}$ The continued strength of anti-vaccination and anti-vivisection voluntary societies in the mid-twentieth century also made central government wary of the public backlash from instituting any national mass immunisation programme. ${ }^{72}$ High-profile incidents in which people had been injured or killed through improper use of immunisation gave authorities further justification for remaining cautious. ${ }^{73}$ This book draws attention to the ways in which national public health programmes framed scientific findings and reached divergent conclusions in the post-war period. The burden of proof required before British authorities would declare a vaccine safe or effective was influenced by politics as much as by science. Once Britain finally did establish a national anti-diphtheria strategy, the success of this campaign softened attitudes. From the 1940s onwards the Medical Research Council (MRC) began to seriously consider other immunisations as potential additions to the public health system. ${ }^{74}$

The success of mass immunisation through the first half of the twentieth century established it as a key tool in public health. This encouraged the development of new vaccines and the willingness of states to consider using them as part of immunisation programmes. During the Second World War, coordination of political aims and scientific research had seen a number of advancements in medicine as a direct contribution to the war effort, including the protection of troops from potential biological warfare and the demands of operating in foreign climates. ${ }^{75}$ Contemporary advancements in virology and immunology offered the possibility of controlling - perhaps even eradicating - other infectious diseases, old and new. ${ }^{76}$ It is these developments which the chapters of this book discuss in greater detail. The book starts in 1945, in the afterglow of a successful anti-diphtheria campaign by the wartime coalition government. Despite some initial scepticism, immunisation rates grew significantly over the course of the 1940s, and diphtheria morbidity and mortality dropped significantly. With the prospect on the horizon of using new vaccinations against tuberculosis and pertussis 
(whooping cough), as well as the new state-run NHS, public health and vaccination were both primed for significant administrative and political transformations.

\section{Chapter outline}

Given this history, it is clear that vaccination programmes - like any other political project - are rooted in a wider social context. The book explores this through a series of case studies which highlight the ways in which the public and governments interacted, shaping public health as they went. What was expected of the public and of the government changed over this period; and the debates over vaccination show wider concerns about the relationship between the state and its citizens. In explaining how vaccination became ordinary, the volume is split into two parts. Part I shows how the vaccination programme in Britain as we know it today was created and evolved. Part II deals with vaccination crises within an already-established system. The two parts comprise five chapters which explain these trends through five interrelated themes. Each represents a different area of responsibility or expectation on the part of both the public and public health authorities.

Part I begins with apathy. Chapter 1 explores this through the diphtheria immunisation programme. Diphtheria immunisation was introduced on a national basis during the Second World War and was initially successful - so much so, that it formed the basis of the voluntary vaccination system that replaced the Victorian Vaccination Acts with the birth of the NHS. In 1949, however, declining vaccination rates concerned the Ministry of Health. The drop was blamed on apathetic parents (particularly mothers), and the Ministry hoped to combat this by reminding parents of young children how dangerous diphtheria still was. When parents did not have their children vaccinated, they could be accused of negligence. However, public health authorities also understood that the reasons for non-vaccination were various and complex. How they used apathy as a rhetorical device in setting local immunisation targets and health education said much about what was considered reasonable behaviour on the part of parents. And, indeed, what reasonable behaviour the public expected of each other.

Chapter 2 examines nation. The British vaccination programme was very much a national project. However, it could not function without 
implementation at the local level and was dependent on international networks of vaccine knowledge. At the same time, the programme exposed the limits of national power and raised questions about who the "British public" were that required protection through public health policy. Elimination of disease within British borders was as vital as preventing the importation of once-eliminated infections from foreign places and peoples. This is examined through debates over the smallpox vaccine from the end of the war in 1945 to the end of routine childhood smallpox vaccination in 1971. Here too, apathy was an important concept. Vaccination rates remained stubbornly low for a disease long since eliminated from British shores. And yet, whenever there was a local outbreak queues would stretch from local Medical Officers' clinics, demanding emergency vaccination to protect local citizens from the disease. The public's view of what protections the government ought to provide - and the form they should take - were not always aligned with the Ministry's.

This leads to the third and final chapter in Part I, which analyses demand. While governments were undoubtedly concerned with disciplining parents who did not conform with official advice, members of the public themselves demanded that the state should make immunisation services available to all. In an advanced economy such as Britain's, the expectation that the state would protect citizens from manageable risks became commonplace. Chapter 3 uses the inactivated polio vaccine programme to show the difficult relationship between what the public demanded and what the government was able or willing to provide. The place of the nation was still important here. This was a national programme, but, like all vaccination at this time, it was administered by local authorities who had differing results in terms of uptake. Despite the demand from some quarters, in others the government still had a hard time overcoming what it perceived to be an apathetic public. Similarly, production of the vaccine was made possible only through large-scale cooperation with other nations; and the relationship between British pharmaceutical companies, foreign nations and the British government was key.

Part II begins in the early 1970s. By this time, smallpox vaccination had been removed from the schedule, while polio and diphtheria immunisation were now well established. They were joined by BCG (in schools), pertussis, measles and tetanus. Vaccination had become 
commonplace, and it was widely accepted that routine childhood immunisation was a useful and important public health tool. However, controversies did rear their heads. The public had consented and cooperated with British public health authorities in developing the vaccination programme. This meant that when confidence in the medical and political establishments became strained, so did faith in vaccination - at least in the case of specific vaccines at specific times. And yet, such crises did not destroy the vaccination or public health systems entirely, and confidence soon recovered.

Thus, Chapter 4 examines risk through the 1970s pertussis vaccine crisis. Risk pervaded all aspects of vaccination policy - indeed public health is inherently about the management of disease risks. Attitudes toward which risks were acceptable and which risks were manageable changed considerably during the post-war period, however. Governments had to manage the risks of damage to their reputation from potentially unsafe vaccines versus the benefits of disease control. The public also pushed back against government policy when it felt certain that risks were unacceptable or were being poorly managed. Many other themes can also be identified here. Public health authorities struggled against a form of apathy: the idea that parents no longer feared pertussis because of the success of the vaccination programme. So too did they have to deal with a form of demand. Parents demanded protection for their children, both from the disease and from the vaccine itself. They understood the risks to their children differently from public health authorities, causing greater tension. Once the scientific basis for the vaccine was re-established and an epidemic loomed on the horizon, there was such demand for the vaccine that many local authorities ran short of it. This led to discussions which reflected wider contemporary concerns about the role of the national government and a deeper political crisis in the welfare state.

Finally, Chapter 5 brings these themes together and examines hesitancy, a concept that made an entry into global vaccination policy around the year 2010, but that is clearly a product of the lessons that public health has taken from its own history. Recent vaccine crises and narratives that changing approaches to the meaning of "health" in the World Health Organization have led social scientists to focus on individuals' decision-making processes. These start from the premise that uptake of vaccination ought to be universal and that the declines in 
vaccination rates are not only a sign of wider problems but are also to some extent preventable with adequate communication and monitoring. None of this can be understood without reference to the changing face of apathy, demand, nation and risk in previous decades. This history is explained in Chapter 5 through the changes in government policy during the MMR crisis in the late 1990s and 2000s. Some parents were accused of apathy due to much-reduced measles morbidity since the introduction of measles vaccination in 1961 and of MMR vaccination in 1988. But this does not capture why the majority of parents made the decision to continue to vaccinate, even during the height of the crisis. Nor does it explain why many opponents of MMR vaccination demanded that the government make separate measles, mumps and rubella vaccines available to any parent who asked for them. As with the pertussis crisis, the public's understanding of risk and the reasons for their hesitancy did not always accord with expert opinion. National and devolved authorities used risk-communication techniques and comparisons with other nations to reassert the safety and utility of MMR vaccination when it became clear that the health education tactics of previous decades were not having the desired effect. This shift from education towards analysis of decision making and risk would be a key facet of twenty-first-century public health.

\section{Notes}

1 Raya Jalabi, 'California declares Disneyland measles outbreak over as vaccine fight rages on', Guardian (17 April 2015) https://www.theguardian. $\mathrm{com} /$ society/2015/apr/17/california-declares-disneyland-measlesoutbreak-over (accessed 12 January 2018).

2 World Health Organization, 'Measles continues to spread and take lives in Europe' (11 July 2017) www.euro.who.int/en/media-centre/sections/ press-releases $/ 2017 /$ measles-continues-to-spread-and-take-lives-ineurope (accessed 12 January 2018); Michael Day, 'Doctor and MPs in Italy are assaulted after vaccination law is passed', British Medical Journal, 358 (2017), j3721; Sophie Arie, 'Compulsory vaccination and growing measles threat', British Medical Journal, 358 (2017), j3429.

3 David Callender, 'Vaccine hesitancy: More than a movement', Human Vaccines \& Immunotherapeutics, 12:9 (2016), 2464-8; Eve Dubé, Maryline Vivion and Noni E. MacDonald, 'Vaccine hesitancy, vaccine refusal and the anti-vaccine movement: influence, impact and implications', Expert 
Review of Vaccines, 14:1 (2015), 99-117; Kenneth Camargo and Roy Grant, 'Public health, science, and policy debate: Being right is not enough', American Journal Public Health, 105:2 (2014), 232-5; Ross S. Federman, 'Understanding vaccines: A public imperative', Yale Journal of Biology and Medicine, $87: 4$ (2014), 417-22.

4 WHO, Rotary International, Centers for Disease Control and Prevention and UNICEF, Global Polio Eradication Initiative Status Report 29 April 2013 (Geneva: Global Polio Eradication Initiative, 2013).

5 The argument against vaccinating only teenage girls has taken two forms: one, that males can carry HPV and therefore ought to be vaccinated to protect females; and two, that since HPV can cause cancer in males, they ought to be offered the same protection. See Aruna Nigam, Pikee Saxena, Anita S. Acharya, Archana Mishra and Swaraj Batra, 'HPV vaccination in India: Critical appraisal', ISRN Obstetrics and Gynecology (2014), 1-5; Fouzieyha Towghi, 'The biopolitics of reproductive technologies beyond the clinic: Localizing HPV vaccines in India', Medical Anthropology, 32:4 (2013), 325-42; Heidi Larson, 'The world must accept that the HPV vaccine is safe', Nature, 528:7580 (2015), 9; Catriona Kennedy, Carol Gray Brunton and Rhona Hogg, " "Just that little bit of doubt": Scottish parents', teenage girls' and health professionals' views of the MMR, H1N1 and HPV vaccines', International Journal of Behavioral Medicine, 21:1 (2014), 3-10; Monica J. Casper and Laura M. Carpenter, 'Sex, drugs, and politics: the HPV vaccine for cervical cancer', Sociology of Health \& Illness, 30:6 (2008), 886-99; Telegraph, 'Boys should get HPV vaccine to protect them from throat cancers, experts say', Telegraph (10 July 2016) www.telegraph.co.uk/news/2016/07/09/boys-should-get-hpv-vaccineto-protect-them-from-throat-cancers/ (accessed 19 August 2016).

6 World Health Organization, 'WHO Director-General summarizes the outcome of the Emergency Committee regarding clusters of microcephaly and Guillain-Barré syndrome' (2016) www.who.int/mediacentre/news/ statements/2016/emergency-committee-zika-microcephaly/en/ (accessed 19 August 2016); Siddhartha Mukherjee, 'The race for a Zika vaccine', New Yorker (22 August 2016) www.newyorker.com/magazine/ 2016/08/22/the-race-for-a-zika-vaccine (accessed 19 August 2016); Tulip Mazumdar, 'Zika vaccine possible "within months", BBC News (4 March 2016) www.bbc.co.uk/news/health-35727047 (accessed 19 August 2016); Linda Carroll and Samuel Sarmiento, " "Striking" results from early Zika vaccine trial', NBC News (4 August 2016) www.nbcnews.com/storyline/ zika-virus-outbreak/striking-results-early-zika-vaccine-trial-n623016 (accessed 19 August 2016). 
7 World Health Organization, 'Statement on the 1st meeting of the IHR Emergency Committee on the 2014 Ebola outbreak in West Africa', (2014) www.who.int/mediacentre/news/statements/2014/ebola-20140808/ en/ (accessed 19 August 2016); Vauhini Vara, 'The race for an Ebola vaccine', New Yorker (25 November 2014) www.newyorker.com/business/ currency/race-ebola-vaccine (accessed 19 August 2016); Anne RoemerMahler and Stefan Elbe, 'The race for Ebola drugs: Pharmaceuticals, security and global health governance', Third World Quarterly, 37:3 (2016), 487-506; Declan Butler, Ewen Callaway and Erika Check Hayden, 'How Ebola-vaccine success could reshape clinical-trial policy', Nature, 524:7563 (2015), 13-14.

$8 \mathrm{Hib}-$ Haemophilus influenza type b - is an infection that can cause meningitis, septicaemia, pneumonia and other complications. See Health and Social Care Information Centre, 'NHS Immunisation Statistics: England, 2014-15’ (23 September 2015) http://digital.nhs.uk/catalogue/ PUB18472/nhs-immu-stat-eng-2014-15-rep.pdf (accessed 23 August 2017). Acceptance rates fell slightly in the two following years but remain high: 91.6 per cent for MMR and 93.4 per cent for the five-inone in 2016-17. NHS Digital, 'Childhood vaccination coverage statistics, England, 2016-17’ (20 September 2017) https://digital.nhs.uk/catalogue/ PUB30085 (accessed 12 January 2018).

9 In 2014-15, 95.4 per cent of children under the age of 2 received MMR, while over 97 per cent received the five-in-one. National Health Services Scotland, 'Childhood Immunisation Statistics Scotland: Quarter and Year Ending 31 December 2015’ (22 March 2016) www.isdscotland.org/ Health-Topics / Child-Health/Publications / 2016-03-22/201603-22-Immunisation-Report.pdf (accessed 23 August 2017), p. 5.

10 Heidi J. Larson, Alexandre de Figueiredo, Zhao Xiahong, William S. Schulz, Pierre Verger, Iain G. Johnston, Alex R. Cook and Nick S. Jones, 'The state of vaccine confidence 2016: Global insights through a 67-country survey', EBioMedicine, 12 (2016), 295-301.

11 It has been surpassed (as at 15 February 2018) only by the campaign to re-run the 2016 European Union referendum and demands that Donald Trump's 2017 state visit be cancelled. UK Government and Parliament Petitions, 'Petition: Give the meningitis B vaccine to ALL children, not just newborn babies' (15 September 2015) https://petition.parliament.uk/ petitions/108072 (accessed 20 August 2016); 'Meningitis B petition becomes UK's most signed', BBC News (19 February 2016) www.bbc.co.uk/ news/uk-england-kent-35614846 (accessed 20 August 2016); James Cusick, 'Meningitis B: Petition calling for vaccine breaks government 
website record', Independent (19 February 2016) www.independent.co.uk/ life-style/health-and-families/health-news/meningitis-b-petition-callingfor-vaccine-breaks-government-website-record-a6884946.html (accessed 20 August 2016).

12 Jacob Heller, The Vaccine Narrative (Nashville, TN: Vanderbilt University Press, 2008), p. 1.

13 National Health Service, 'Childhood vaccines timeline' (16 July 2016) www.nhs.uk/Conditions/Vaccinations/Pages/Childhood-vaccinationschedule.aspx (accessed 12 January 2018).

14 Stuart Blume, Immunization: How Vaccines Became Controversial (London: Reaktion, 2017).

15 Ibid. See also Paul Greenough, Stuart Blume and Christine Holmberg, 'Introduction', in Christine Holmberg, Stuart Blume and Paul Greenough (eds), The Politics of Vaccination: A Global History (Manchester: Manchester University Press, 2017), pp. 1-16.

16 Eugene Straus and Alex Straus, Medical Marvels: The 100 Greatest Advances in Medicine (Amherst, NY: Prometheus Books, 2006); Arthur Allen, Vaccine: The Controversial Story of Medicine's Greatest Lifesaver (New York: W. W. Norton, 2007), p. 1; Paul A. Offit, Vaccinated: One Man's Quest to Defeat the World's Deadliest Diseases (New York: Smithsonian Books, 2007); Gareth Williams and Ray Loadman, Paralysed with Fear: The Story of Polio (Basingstoke: Palgrave Macmillan, 2013).

17 Andrew W. Artenstein (ed.), Vaccines: A Biography (New York: Springer, 2010).

18 Andrea Kitta, Vaccinations and Public Concern in History: Legend, Rumor, and Risk Perception (New York: Routledge, 2012); Artenstein (ed.), Vaccines; Paul A. Offit, The Cutter Incident: How America's First Polio Vaccine led to the Growing Vaccine Crisis (New Haven, CT: Yale University Press, 2005); Helen Bedford and David Elliman, 'Concerns about immunisation', British Medical Journal, 320:7229 (2000), 240-3; H. J. Parish, A History of Immunization (Edinburgh: Livingstone, 1965).

19 The debate over the role of medicine and public health on mortality decline since the 1700s has been contested, but this is broadly the consensus among medical professionals. For the debate in historical context see particularly: Thomas McKeown and R. G. Brown, 'Medical evidence related to English population changes in the eighteenth century', Population Studies, 9:2 (1955), 119-41; Simon Szreter, 'The importance of social intervention in Britain's mortality decline c.1850-1914: A re-interpretation of the role of public health', Social History of Medicine, 1:1 (1988), 1-38; James Colgrove, 'The McKeown thesis: A historical controversy and its enduring influence', American Journal of Public Health, 92:5 (2002), 725-9. 
20 For examples of medical professionals' interest in the history of antivaccination moments in history, see Swansea Research Unity of the Royal College of General Practitioners, 'Effect of a low pertussis vaccination take-up on a large community', British Medical Journal (Clinical Research Edition), 282:6257 (1981), 23-6; Mikio Kimura and Harumi Kuno-Sakai, 'Pertussis vaccines in Japan - a clue toward understanding of Japanese attitude to vaccines', Journal of Tropical Pediatrics, 37:1 (1991), 45-7; Robert M. Wolfe and Lisa K. Sharp, 'Anti-vaccinationists past and present', British Medical Journal, 325:7361 (2002), 430-2; Richard Horton, MMR: Science and Fiction - Exploring a Vaccine Crisis (London: Granta Books, 2004); Tammy Boyce, Health, Risk and News: The MMR Vaccine and the Media (New York: Peter Lang, 2007); Paul A. Offit, 'The anti-vaccination epidemic: Whooping cough, mumps and measles are making an alarming comeback, thanks to seriously misguided parents', Wall Street Journal (Online) (24 September 2014) www.wsj.com/articles/paul-a-offitthe-anti-vaccination-epidemic-1411598408 (accessed 19 August 2016). Offit's review of the Cutter Incident is more rounded, but explicitly calls for lessons to be learned so that the reputation of vaccination can be defended. Offit, The Cutter Incident. Some historical investigations have begun to move away from this narrative as more historical data have become available. See Jeffrey P. Baker, 'The pertussis vaccine controversy in Great Britain, 1974-1986', Vaccine, 21:25-26 (2003), 4003-10; Jan Hendriks and Stuart Blume, 'Measles vaccination: Before the measlesmumps-rubella vaccine', American Journal of Public Health, 103:8 (2013), 1393-401; Rachel Casiday, 'Risk communication in the British pertussis and MMR vaccine controversies', in Peter Bennett, Kenneth Calman, Sarah Curtis and Denis Fischbacher-Smith (eds), Risk Communication and Public Health (Oxford: Oxford University Press, 2010), 129-46; Alison Day, "An American tragedy". The Cutter Incident and its implications for the Salk polio vaccine in New Zealand 1955-1960', Health \& History: Journal of the Australian \& New Zealand Society for the History of Medicine, 11:2 (2009), 42-61; Per Axelsson, 'The Cutter Incident and the development of a Swedish polio vaccine, 1952-1957', Dynamis, 32:2 (2012), $311-28$.

21 Virginia Berridge, 'Using history in policy and practice', in Virginia Berridge, Martin Gorsky and Alex Mold, Public Health in History (Maidenhead: Open University Press, 2011), p. 215.

22 Dorothy Porter and Roy Porter, "The politics of prevention: Antivaccinationism and public health in nineteenth-century England', Medical History, 32:3 (1988), 231-52; E. P. Hennock, 'Vaccination policy against smallpox, 1835-1914: A comparison of England with Prussia and Imperial 
Germany', Social History of Medicine, 11:1 (1998), 49-71; Nadja Durbach, Bodily Matters: The Anti-Vaccination Movement in England, 1853-1907 (Durham, NC: Duke University Press, 2005), p. 1; Stanley Williamson, The Vaccination Controversy: The Rise, Reign, and Fall of Compulsory Vaccination for Smallpox (Liverpool: Liverpool University Press, 2007); Michael Bennett, 'Jenner's ladies: Women and vaccination against smallpox in early nineteenth-century Britain', History, 93:312 (2008), 497-513.

23 Dora Vargha, 'Between East and West: Polio vaccination across the Iron Curtain in Cold War Hungary', Bulletin of the History of Medicine, 88:2 (2014), 319-42; Ulrike Lindner and Stuart S. Blume, 'Vaccine innovation and adoption: Polio vaccines in the UK, the Netherlands and West Germany, 1955-1965', Medical History, 50:4 (2006), 425-46.

24 Jane Lewis, 'The prevention of diphtheria in Canada and Britain 1914-1945', Journal of Social History, 20:1 (1986), 163-76; Linda Bryder, "'We shall not find salvation in inoculation": BCG vaccination in Scandinavia, Britain and the USA, 1921-1960', Social Science \& Medicine, 49:9 (1999), 1157-67; Claire Hooker, 'Diphtheria, immunisation and the Bundaberg Tragedy: A study of public health in Australia', Health and History, 2:1 (2000), 52-78; Lindner and Blume, 'Vaccine innovation and adoption'; Alison Day, " "The magical formula": Reactions and responses to diphtheria immunisation in New Zealand 1920-1960', Health \& History: Journal of the Australian \& New Zealand Society for the History of Medicine, 15:2 (2013), 53-71.

25 On governmentality and medicine, see Alan R Petersen and Deborah Lupton, The New Public Health: Health and Self in the Age of Risk (London: Sage Publications, 2000); Michel Foucault, The Birth of the Clinic: An Archaeology of Medical Perception (London: Tavistock, 1973); David Armstrong, Political Anatomy of the Body: Medical Knowledge in Britain in the Twentieth Century (Cambridge: Cambridge University Press, 1983).

26 For example, Bryder, 'BCG vaccination'; Lewis, 'The Prevention of diphtheria'; Lindner and Blume, 'Vaccine innovation and adoption'; Jennifer Stanton, 'What shapes vaccine policy? The case of hepatitis B in the UK', Social History of Medicine, 7:3 (1994), 427-46.

27 Peterson and Lupton, The New Public Health.

28 Rudolf Klein, The New Politics of the NHS: From Creation to Reinvention, 7th edn (Oxford: Radcliffe, 2013).

29 James Colgrove, State of Immunity: The Politics of Vaccination in TwentiethCentury America (Berkeley: University of California Press, 2006).

30 Sanjoy Bhattacharya, Expunging Variola: The Control and Eradication of Smallpox in India, 1947-1977 (New Delhi: Orient Longman, 2006); Bob H. Reinhardt, The End of a Global Pox: America and the Eradication of 
Smallpox in the Cold War Era (Chapel Hill: University of North Carolina Press, 2015).

31 Blume, Immunization.

32 On the Victorian era, see Graham Mooney, Intrusive Interventions: Public Health, Domestic Space, and Infectious Disease Surveillance in England, 1840-1914 (Rochester, NY: University of Rochester Press, 2015); Anne Hanley, Medicine, Knowledge and Venereal Diseases in England, 1886-1916 (Basingstoke: Palgrave Macmillan, 2016). On the twentieth century, and particularly the inter-war period, see Charles Webster, 'Healthy or hungry thirties?', History Workshop, 13 (1982), 110-29; Jane Lewis, What Price Community Medicine? The Philosophy, Practice, and Politics of Public Health Since 1919 (Brighton: Wheatsheaf, 1986); John Welshman, Municipal Medicine: Public Health in Twentieth-century Britain (Bern: Peter Lang, 2000); John Welshman, 'Compulsion, localism, and pragmatism: The micro-politics of tuberculosis screening in the United Kingdom, 1950-1965, Social History of Medicine, 19:2 (2006), 295-312; Martin Gorsky, 'Public health in interwar Britain: Did it fail?', Dynamis, 28 (2008), 175-98; Jane K. Seymour, Martin Gorsky and Shakoor Hajat, 'Health, wealth and party in inter-war London', Urban History, 44:3 (2017), 464-91.

33 Roberta Bivins, " "The people have no more love left for the Commonwealth": Media, migration and identity in the 1961-62 British smallpox outbreak', Immigrants \& Minorities, 25:3 (2007), 263-89; Roberta E. Bivins, Contagious Communities: Medicine, Migration, and the NHS in PostWar Britain (Oxford: Oxford University Press, 2015). See also Petersen and Lupton, The New Public Health; Richard Coker, 'Civil liberties and public good: Detention of tuberculous patients and the Public Health Act 1984', Medical History, 45:3 (2001), 341-58; Steve Sturdy, 'Introduction: Medicine, health and the public sphere', in Steve Sturdy (ed.), Medicine, Health and the Public Sphere in Britain: 1600-2000 (London: Routledge, 2002), pp. 1-24; David Cantor, 'Representing "the public": Medicine, charity and the public sphere in twentieth-century Britain', in Steve Sturdy (ed.), Medicine, Health and the Public Sphere in Britain: 1600-2000 (London: Routledge, 2002), pp. 145-68; Pamela K. Gilbert, 'Producing the public: Public medicine in private spaces', in Steve Sturdy (ed.), Medicine, Health and the Public Sphere, 43-59; M. F. Verweij and Angus Dawson, "The meaning of "public" in "public health", in M. F. Verweij and Angus Dawson (eds), Ethics, Prevention, and Public Health (Oxford: Clarendon Press, 2007), pp. 13-29; John T. MacFarlane and Michael Worboys, 'Showers, sweating and suing: Legionnaires' disease and "new" infections in Britain, 1977-90', Medical History, 56:1 (2012), 72-93. 
34 Dorothy Porter, Health Citizenship: Essays in Social Medicine and Biomedical Politics (Berkeley: University of California Press, 2011), 213-15; Nike Ayo, 'Understanding health promotion in a neoliberal climate and the making of health conscious citizens', Critical Public Health, 22:1 (2012), 99-105; Frank Huisman and Harry Oosterhuis, 'The politics of health and citizenship: Historical and contemporary perspectives', in Frank Huisman and Harry Oosterhuis (eds), Heath and Citizenship: Political Cultures of Health in Modern Europe (London: Pickering and Chatto 2014), pp. 1-40.

35 On these themes see Petersen and Lupton, The New Public Health; Virginia Berridge and Alex Mold, 'Professionalisation, new social movements and voluntary action in the 1960s and 1970s', in Matthew Hilton and James McKay (eds), The Ages of Voluntarism: How we got to the Big Society (Oxford: Oxford University Press, 2011), pp. 114-34; Alex Mold, Making the Patient-consumer: Patient Organisations and Health Consumerism in Britain (Manchester: Manchester University Press, 2015).

36 On risk, see Chapter 4 and Ulrich Beck, Risk Society: Towards a New Modernity (London: Sage, 1992); Mary Douglas and Aaron Wildavsky, Risk and Culture (Berkeley: University of California Press, 1983); Jakob Arnoldi, Risk: An Introduction (Cambridge: Polity, 2009); Baruch Fischoff and John Kadvany, Risk: A Very Short Introduction (Oxford: Oxford University Press, 2011).

37 On technocracy see David Edgerton, 'C. P. Snow as anti-historian of British science: Revisiting the technocratic moment, 1959-1964', History of Science 43:2 (2005), 187-208; Mike Savage, 'Affluence and social change in the making of technocratic middle-class identities: Britain, 1939-55', Contemporary British History, 22:4 (2008): 457-76.

38 For authors with medical qualifications looking back on the efficacy of vaccines and their worth as public health tools, see Parish, A History of Immunization; Kimura and Kuno-Sakai, 'Pertussis vaccines in Japan'; Baker, 'The pertussis vaccine controversy'; David M. Oshinsky, Polio: An American Story (Oxford: Oxford University Press, 2005); Offit, Vaccinated; Artenstein (ed.), Vaccines; Williams and Loadman, Paralysed with Fear.

39 Florence Sutcliffe-Braithwaite, 'Discourses of "class" in Britain in "New Times", Contemporary British History, 31:2 (April 2017), 294-317.

40 On the role of folklorists using ethnography to access understandings and meanings of health, see Diane E. Goldstein, Once Upon a Virus: AIDS Legends and Vernacular Risk Perception (Logan: Utah State University Press, 2004); Kitta, Vaccinations and Public Concern in History.

41 As an example of this, see James Hanley's work on nineteenth-century parliamentary petitions as a way of understanding public reaction to 
policy: James G. Hanley, 'The public's reaction to public health: Petitions submitted to parliament, 1847-1848', Social History of Medicine, 15:3 (2002), 393-411. See also Daisy Payling on "complaints" to the social survey: Daisy Payling, " "The people who write to us are the people who don't like us": Public responses to the Government Social Survey's Survey of Sickness, 1943-1952', Journal of British Studies (forthcoming, 2018).

42 On AIDS, see Jon Cohen, Shots in the Dark: The Wayward Search for an AIDS Vaccine (New York: Norton, 2001); Patricia Thomas, Big Shot: Passion, Politics, and the Struggle for an AIDS Vaccine (New York: Public Affairs, 2001); Heller, The Vaccine Narrative.

43 Colgrove, State of Immunity.

44 Sturdy, 'Introduction'; Petersen and Lupton, The New Public Health, p. 55.

45 Foucault, The Birth of the Clinic; Armstrong, Political Anatomy of the Body; Mooney, Intrusive Interventions.

46 Lewis, What Price Community Medicine?

47 Hanley, Medicine, Knowledge and Venereal Diseases; Hanley, 'The public's reaction to public health'; Mooney, Intrusive Interventions; Michael Worboys, Spreading Germs: Disease Theories and Medical Practice in Britain, 1865-1900 (Cambridge: Cambridge University Press, 2000).

48 Ibid.

49 John Welshman, 'The Medical Officer of Health in England and Wales, 1900-1974: Watchdog or lapdog?', Journal of Public Health, 19:4 (1997), 443-50; Gorsky, 'Public health in interwar Britain'.

50 Virginia Berridge, Marketing Health (Oxford: Oxford University Press, 2007).

51 Ibid.

52 Diana Barnes, 'The public life of a woman of wit and quality: Lady Mary Wortley Montagu and the vogue for smallpox inoculation', Feminist Studies, 38:2 (2012), 330-62; Anne Eriksen, 'Advocating inoculation in the eighteenth century: Exemplarity and quantification', Science in Context, 29:2 (2016), 213-39.

53 Anne Eriksen, 'Cure or protection? The meaning of smallpox inoculation, ca 1750-1775', Medical History, 57:4 (2013), 516-36.

54 Edward Jenner, An Inquiry into the Causes and Effects of the Variolee Vaccince a Disease Discovered in Some of the Western Counties of England, Particularly Gloucestershire and Known by the Name of the Cow Pox (London: Sampson Low, 1789). Benjamin Jesty is often credited as the "inventor" of vaccination, but there were others who had written about cowpox and its potential as a prophylactic against smallpox. See Colin R. Howard, 'The impact on public health of the 19th century anti-vaccination movement', Microbiology 
Today, 30:1 (February 2003), 22-5; Frank Fenner, Donald A. Henderson, Isao Arita, Jezek Zdenek, Ivan Danilovich Ladnyi and World Health Organization, Smallpox and Its Eradication (Geneva: World Health Organization, 1988), p. 258.

55 Vaccination Acts were passed in 1840, 1853, 1867, 1871, 1873, 1898 and 1907. See Deborah Brunton, The Politics of Vaccination: Practice and Policy in England, Wales, Ireland, and Scotland, 1800-1874 (New York: University Rochester Press, 2008); Hardy, The Epidemic Streets: Infectious Disease and the Rise of Preventive Medicine, 1856-1900 (Oxford; New York: Clarendon Press ; Oxford University Press, 1993), pp. 110-50.

56 R. E. Spier, 'Perception of risk of vaccine adverse events: a historical perspective', Vaccine, 20:Supplement 1 (2001), S78-S84; Colgrove, State of Immunity; Nadja Durbach, 'Class, gender, and the conscientious objector to vaccination, 1898-1907', Journal of British Studies, 41:1 (2002), 58-83; Durbach, 'Bodily matters'.

57 Foucault, The Birth of the Clinic; Armstrong, Political Anatomy of the Body; Mooney, Intrusive Interventions.

58 As with Jenner and vaccination, there is debate about who was the first to create laboratory-based vaccines, but Pasteur was the first to demonstrate their benefits on a larger scale. Maurice Cassier, 'Producing, controlling, and stabilizing Pasteur's anthrax vaccine: Creating a new industry and a health market', Science in Context, 21:2 (2008), 253-78; John D. Grabenstein, 'Toxoid vaccines', in Andrew W. Artenstein (ed.), Vaccines: A Biography (New York: Springer, 2010), pp. 105-24.

59 Worboys, Spreading Germs; Anne Marie Moulin, 'La metaphore vaccine: de l'inoculation a la vaccinologie', History \& Philosophy of the Life Sciences, 14:2 (1992), 271-97; Kendall A. Smith, 'Louis Pasteur, the father of immunology?', Frontier in Immunology, 3:68 (2012). See also Frank C. Schmalstieg and Armond S. Goldman, 'Birth of the science of immunology', Journal of Medical Biography, 18:2 (2010), 88-98; Steven M. Opal, 'A brief history of microbiology and immunology', in Andrew W. Artenstein (ed.), Vaccines: A Biography (New York: Springer, 2010), pp. 31-56.

60 Esteban Rodríguez Ocaña, 'The social production of novelty: Diphtheria serotherapy, "herald of the new medicine"', Dynamis, 27 (2007), 21-31. See also the special edition of Dynamis on diphtheria immunisation, including: Gabriel Gachelin, 'The designing of anti-diphtheria serotherapy at the Institut Pasteur (1888-1900): The role of a supranational network of microbiologists', Dynamis, 27 (2007), 45-62; Jonathan Simon, 'The origin of the production of diphtheria antitoxin in France, between philanthropy and commerce', Dynamis, 27 (2007), 63-82; Axel C. Hüntelmann, 
'Diphtheria serum and serotherapy. Development, production and regulation in "Fin De Siecle" Germany', Dynamis, 27 (2007), 107-31.

61 Heller, The Vaccine Narrative.

62 W. W. C. Topley and G. S. Wilson, 'The spread of bacterial infection. The problem of herd-immunity', The Journal of Hygiene, 21:3 (1923), 243-9.

63 Cassier, 'Producing, controlling, and stabilizing Pasteur's anthrax vaccine'.

64 Ocaña, 'The social production of novelty'.

65 Colgrove, State of Immunity.

66 Although, as Patrick Carroll argues, British public health did engage in its own form of policing, and the dichotomy between the British and German systems is more rhetorical than it appears in practice. Patrick E. Carroll, 'Medical police and the history of public health', Medical History, 46:4 (2002), 461-94.

67 See Berridge, Marketing Health.

68 Bryder, 'BCG vaccination'; Lewis, 'The prevention of diphtheria'.

69 Ibid.

70 Ibid.

71 Lewis, 'The Prevention of diphtheria'; Welshman, 'The Medical Officer of Health in England and Wales, 1900-1974'; Gorsky, 'Public health in interwar Britain'.

72 Lewis, 'The Prevention of diphtheria'. See, for example, the government files detailing correspondence between such groups as the Anti-Vaccination League and the British Union for the Abolition of Vivisection in: The National Archives (hereafter TNA): MH 55/293; MH 55/1720; HO 45/10768/273078; and passim.

73 See Hooker, 'Diphtheria, immunisation and the Bundaberg tragedy'; Peter Hobbins, "Immunisation is as popular as a death adder": The Bundaberg Tragedy and the politics of medical science in interwar Australia', Social History of Medicine, 24:2 (2011), 426-44; Day, '“The magical formula"'; Parish, A History of Immunization, pp. 151-3.

74 Trials were published in: Percival Horton-Smith Hartley, A Study of Diphtheria in Two Areas of Great Britain: With Special Reference to the Antitoxin Concentration of the Serum of Inoculated and Non-inoculated Patients and Other Persons; and the Relation of this to the Incidence, Type and Severity of the Disease (London: HMSO, 1950); Medical Research Council, 'B.C.G. and vole bacillus caccines in the prevention of tuberculosis in adolescents', British Medical Journal, 1:4964 (1956), 413-27; Medical Research Council, 'B.C.G. and vole bacillus vaccines in the prevention of tuberculosis in adolescents', British Medical Journal, 2:5149 (1959), 379-96. See also TNA: FD 1/8290; FD 4/272. 
75 Kendall Hoyt, Long Shot: Vaccines for National Defense (Cambridge, MA: Harvard University Press, 2012); Emma Newlands, Civilians into Soldiers: War, the Body and British Army Recruits, 1939-45 (Manchester: Manchester University Press, 2014).

76 Nicholas C. Artenstein and Andrew W. Artenstein, 'The discovery of viruses and the evolution of vaccinology', Andrew W. Artenstein (ed.), Vaccines: A Biography (New York: Springer, 2010), pp. 141-58. 